\title{
Technologies for Diagnosis and Treatment of Acute Stroke
}

\author{
Final Report for LDRD 95-DI-003
}

J. P. Fitch

February 9, 1998

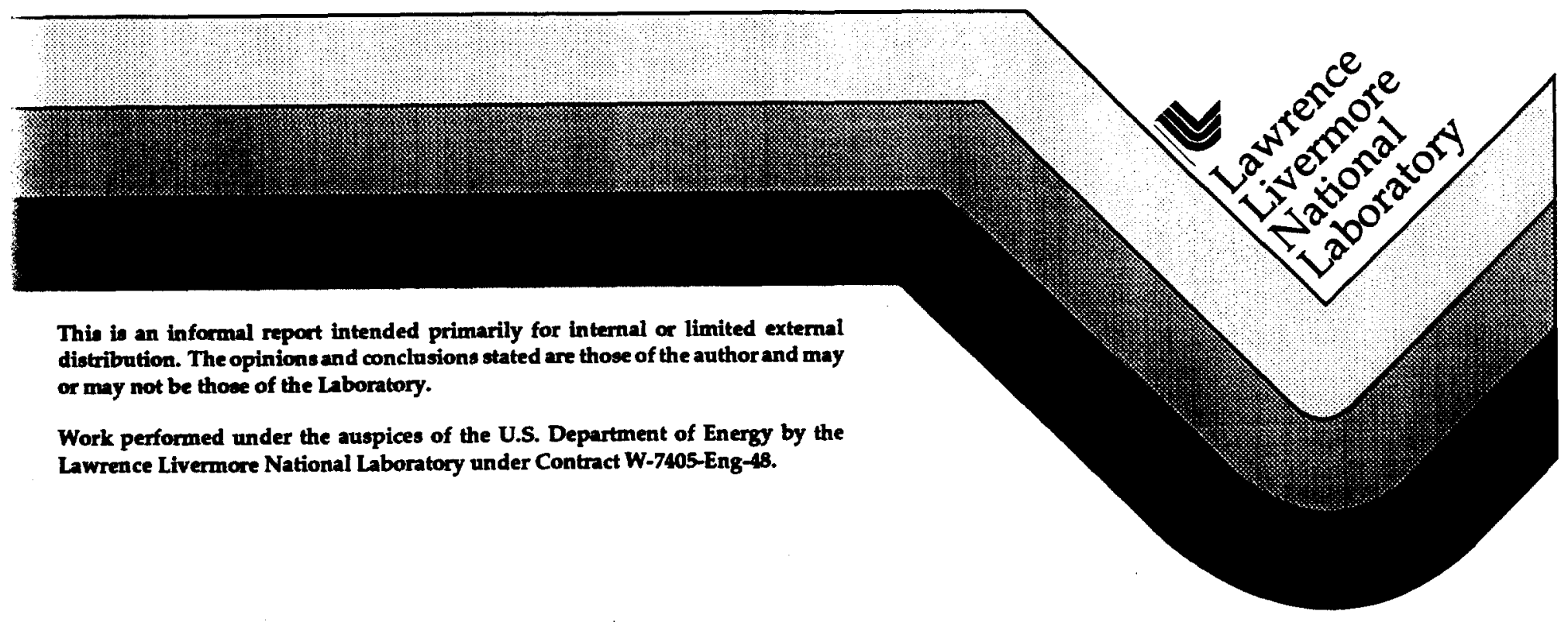




\section{DISCLAIMER}

This document was prepared as an account of work sponsored by an agency of the United States Government. Neither the United States Government nor the University of California nor any of their employees, makes any warranty, express or implied, or assumes any legal liability or responsibility for the accuracy, completeness, or usefulness of any information, apparatus, product, or process disclosed, or represents that its use would not infringe privately owned rights. Reference herein to any specific commercial product, process, or service by trade name, trademark, manufacturer, or otherwise, does not necessarily constitute or imply its endorsement, recommendation, or favoring by the United States Government or the University of California. The views and opinions of authors expressed herein do not necessarily state or reflect those of the United States Government or the University of California, and shall not be used for advertising or product endorsement purposes.

This report has been reproduced directly from the best available copy.

Available to DOE and DOE contractors from the Office of Scientific and Technical Information P.O. Box 62, Oak Ridge, TN 37831

Prices available from (423) 576-8401

Available to the public from the National Technical Information Service

U.S. Department of Commerce

5285 Port Royal Rd.

Springfield, VA 22161 


\section{Technologies for Diagnosis and Treatment of Acute Stroke}

Final Report for LDRD 95-DI-003

J. P. Fitch, Principal Investigator

February 9, 1998

From October 1994 to June 1997, a multidisciplinary team of scientists and engineers at Lawrence Livermore National Laboratory were funded through LDRD to develop and integrate technologies for diagnosis and treatment of acute stroke. The project was summarized in a Science and Technology Review Article "Brain Attack" that appeared in June 1997 and again in the Center for Healthcare Technologies Report (UCRL-LR-124761). This article is the best overview of the project, epidemiology of stroke and technical progress. Most of the technical progress has been documented in conference papers and presentations and refereed journal articles (see references). Additional technical publications can be expected as our remaining patent applications progress through the US Patent \& Trademark Office.

The purpose of this report is to provide an appropriate introduction and organization to the numerous publications so that interested readers can quickly find information. Because there is no documentation for the history of this project, this report provides a summary. It also provides the final status report for the LDRD funding.

\section{BACKGROUND-HISTORICAL SUMMARY}

In November 1993, an internal working group (the Health Care Working Group), at LLNL reported to senior management that there were numerous small healthcare technology projects at LLNL and that a more integrated and larger role in this area was possible and appropriate for a National Laboratory. This led to the creation of the Center for Healthcare Technologies (CHT), in December 1993. The CHT had three goals

- Assist existing healthcare projects at LLNL to continue and succeed

- Promote new, larger (greater than $\$ 1 \mathrm{M}$ ), multidisciplinary projects.

- Develop plans for the role of the Federal government in the development of cost-effective healthcare technologies.

With the existence of the CHT, several Directorates including Engineering, Laser Programs, Chemistry \& Material Sciences, Physics and Plant Engineering, jointly proposed an LDRD Director's Initiative in Technologies for Minimally Invasive Medicine. Engineering Directorate under Roger Werne sponsored the LDRD proposal with Allen Northrup (Engineering) 
and Dennis Matthews (Laser Programs) as co-Principal Investigators. The project proposal was for development of several technologies including

- Diode lasers,

- Optical characterization of tissue,

- Plasma-mediated ablation of tissue,

- Microfabricated devices in silicon,

- Improved endoscopes for carpal tunnel release surgery,

- Magnetic resonance imaging compatible materials, and

- Fiber optic and micro electrochemical sensors.

At this time, the CHT was in discussions with the Department of Energy (DOE), regarding a new program for minimally-invasive medical tools. The DOE Technology Transfer Initiative program had a focused call for optical technologies in minimally invasive medicine. It appeared that this area was growing and would receive DOE support and funding.

The LDRD review committee recommended a stronger focus for the project. The Director of the CHT, J. P. Fitch of the Biology and Biotechnology Research Program Directorate, was asked to develop a focus and to become the Principal Investigator for the project. The focus selected was the diagnosis and treatment of stroke. Stroke is the leading cause of permanent disability and the third leading killer in the US. It consumes about $\$ 40$ billion each year and, in 1994, was viewed as non-treatable by medical intervention. Several parts of the original project were eliminated (diode laser development, improved endoscopes for carpal tunnel release surgery and MRI-compatible materials). The project was organized as an integrated team with the engineering support led by Allen Northrup, lasers by Dennis Matthews, numerical modeling by Rich London and sensors by Bob Glass.

A vision of the future for stroke treatment was developed through a workshop hosted by the CHT and attending by leading neurologists, neurosurgeons, cardiologists, radiologists and researchers from medical centers around the country and from Los Alamos National Laboratory. This vision was critical to setting technical priorities and focusing resources on aspects of stroke care with the most leverage. Based on unanimous support from the workshop attendees, it was decided that "clot busting" was the highest priority stroke problem to solve. Several other topics were identified as being amenable to technical solution including aneurysm treatment, particle catchers, screening technologies, blood vessel sensors, brain tissue sensors, and lower cost hemorrhage detection.

The underlying goal oi the LDRD was to solve a significant medical problem-stroke diagnosis and treatment. The application needed to be both a significant medical and economic improvement. Medical device 
development begins as a concept and ends when an FDA-approved device is reimbursed for use. This is a long and expensive process. Our original intent was to use Federally-sponsored R\&D to do reduction to practice and then to license the devices to industry. Unfortunately, the DOE programs in this area never materialized beyond the DOE/TTI projects. This left the LDRD project with no obvious source of follow-on Federal funding. An alternate source of $R \& D$ funding was needed to continue the project's R\&D and to seed the transition to industry. We adopted a funds-in CRADA and licensing strategy that enabled small companies to pursue commercialization of our concepts and provided funding for LLNL to continue R\&D that focused on assisting the company. Through the numerous interactions the CHT had with the medical device industry, the stroke project had the opportunity to fast track several of its ideas into start-up medical device companies. In terms of producing a device that helps patients the soonest, this is a very appealing approach. However, it does not replenish the R\&D that produced the intellectual property which was the basis of the corporate customer/partnerships. We have documented our business-related activities in several reports and presentations under the reference heading business and policy.

\section{FINAL STATUS REPORT}

The technical approach of the project has been described in the overview documents. The components of the project are

- Numerical Modeling. These references describe the improvements made to LLNL's laser-material interaction codes that produced accurate models for laser-tissue simulations.

- Miniature Sensors. These references describe the fiber optic and electrochemical sensors that were developed to allow real-time diagnosis during neurological procedures. Some of these sensors are for direct placement into brain tissue (in craniotomy applications, for instance), and other sensors are for use in the blood vessels to assist in the diagnosis of thrombo-emboli. A number of chemical signatures have been identified that can be used for assessing local tissue viability $(\mathrm{pH})$ and thrombus type (fibrin degradation products or FDP). Experiments were conducted at SUNY Buffalo where we demonstrated the physiological link between $\mathrm{pH}$ and temperature measurements and stroke. Discussions continue with industry regarding licensing several sensors developed in the stroke project.

- Medical Photonics. These references describe the general research capabilities developed as part of this initiative and the application to stroke. A fiber optic system was developed for clot busting. This resulted in a license and funds-in CRADA with EndoVasix, Corp. that is pursuing 
commercialization. The Medical Photonics Laboratory has also become part of UC Davis' DOE Center of Excellence for Laser Medicine.

- Micro Technologies. These references describe the role miniature silicon and plastic devices have in the initiative. We developed several new micro-electro-mechanical systems (MEMS) for cerebrovascular applications. Three different designs for a "gripper" that releases miniature embolic coils have been implemented. These devices directly impact endovascular procedures for treating cerebral aneurysms. One gripper design has been licensed to a medical device company that collaborates with LLNL and is pursing commercialization.

After two and a half years of LDRD support, we accomplished our original goal: we have positioned several LLNL developed medical device concepts to become medical products that promise medical and economic breakthroughs. Only the results of clinical trials will be able to conclusively tell if we succeeded. But at this early stage, two of our devices are on schedule and several more are positioned to be adopted by industry. The clot buster has already been used in successful animal trials performed by our corporate customer/partner and we look forward to more good news as time progresses. Eventually, the clot buster alone might change the lives of over 300,000 Americans each year.

\section{REFERENCES}

\section{Overview/Introductory Document}

1. UCRL-LR-124761 VOL 2, Technologies for Improving Health Care, Volume II "On the offensive against brain attack," pp. 52-59.

\section{Business and Policy}

Meeting Abstracts

1. Fitch, J. P., "Testing a Potential National Strategy for Cost-Effective Medical Technology," SPIE Proc. of Healthcare Technology Policy II; Conference 2499, Paper 37, May 1995 (UCRL-JC-120996).

Numerical Modeling

Refereed publications

1. Glinsky, M. E., R. A. London, G. B. Zimmerman, S. L. Jacques, and J. D. Ols (1996), "Computer Modeling of Endovascular Patch Welding Using Temperature Feedback," Medical Applications of Lasers III, Proc. SPIE 2623.

2. Amendt, P.A., M. Strauss, R. A. London, M. E. Glinsky, D. J. Maitland, P. M. Celliers, S. R. Visuri, D. S. Bailey, D. A. Young, and D. Ho (1997), "Modeling of Bubble Dynamics in Relation to Medical Applications," Laser-Tissue Interaction VIII, S. L. Jacques, Ed., Proc. SPIE 2975. 
3. London, R. A., M. E. Glinsky, B. Zimmerman, D. C. Eder, and S. L. Jacques (1995), "Coupled Light Transport-Heat Diffusion Model for Laser

Dosimetry with Dynamic Optical Properties," Laser-Tissue Interaction VI, Ed. S. L. Jacques, Proc. SPIE 2391, 434 (UCRL-JC-119377).

4. London, R. A., D. S. Bailey, D. A. Young, W. E. Alley, M. D. Feit, A. M. Rubenchik, and J. Neev (1996), "Computational Modeling of Ultra-ShortPulse Ablation of Enamel," Laser-Tissue Interaction VII,. S. L. Jacques, Ed., Proc. SPIE 2681, 233.

5. Amendt, P., M. Strauss, R. A. London, M. E. Glinsky, D. J. Maitland, P. Celliers, S. Visuri, D. S. Bailey, and D. A. Young (1997), "Laser-Initiated Bubble Evolution for Medical Applications: Dynamics and Energetics," J. App. Phys.

6. London, R. A., M. E. Glinsky, G. B. Zimmerman, D. S. Bailey, D. C. Eder, and S. L. Jacques (1997), "Laser-Tissue Interaction Modeling with LATIS," Applied Optics: Opt. Tech. and Biomed. Optics.

7. Glinsky, M. E., R. A London, G. B. Zimmerman, and S. L. Jacques (1995), "Modeling of Endovascular Patch Welding Using the Computer Program LATIS," Laser-Tissue Interactions VI, Proc., S. L. Jacques, Ed., SPIE, 2391, 262 (UCRL-JC-120178).

8. Non-refereed publications

9. Antoun, T. H., L. Seaman, and M. E. Glinsky (1995), "Modeling of Ablation by Photospallation Using the Computer Program PUFF/DFRACT (1995)," Laser-Tissue Interactions VI, S. L. Jacques, Ed., Proc. SPIE, 2391, 262 (UCRLJC-120177).

10. Oraevsky, A. A., L. B. DaSilva, M. D. Feit, M. E. Glinsky, B. M. Mammini, K. L. Paquette, M. D. Perry, A. M. Rubenchik, W. Small IV, and B. C. Stuart (1995), "Plasma-Mediated Ablation of Biological Tissues with Ultra Short Laser Pulses," Laser-Tissue Interactions VI, S. L. Jacques, Ed., Proc. SPIE, 2391, 423, (UCRL-JC-120215).

11. London, R. A., M. E. Glinsky, G. B. Zimmerman, D. C. Eder, and S. L. Jacques (1995), "Coupled Light Transport-Heat Diffusion Model for Laser Dosimetry with Dynamic Optical Properties," Laser-Tissue Interactions VI, , S. L. Jacques, Ed., Proc. SPIE , 2391, 431 (UCRL-JC-119377).

12. Strauss, M., R. A. London, M. E. Glinsky, P. A. Amendt, D. J. Maitland, D. S. Bailey, D. A. Young, and S. L. Jacques (1997), "Computational Modeling of Laser Thrombolysis for Stroke Treatment," Lasers in Surgery: Adv. Characterization, Therapeutics and Systems VI,. R. R. Anderson, Ed., Proc. SPIE 2671, 11.

Miniature Sensors

Meeting Abstracts 
1. Grant, S.A. and R. S. Glass (1997), "Sol-Gel Based Biosensor for Use in Stroke Treatment." submitted to IEEE Trans. Biomed. Eng., September 1997.

2. Grant, S. A. and R. S. Glass, (1996), "Development of A D Dimer Biosensor to Monitor Stroke Patients During Thrombolytic Therapy," Society for Biomaterials.

3. Grant, S. A. and R. S. Glass (1996), "Development of Sensors to Monitor Stroke Patients," Sixth International Meeting on Chemical Sensors, NIST (UCRL-JC-122915-Abs.).

Non-Refereed publications

1. Grant, S.A. and R. S. Glass (1997), "Sol-Gel Based Biosensor for Fibrinolytic Products," Laser-Tissue Interaction VIII, S. L. Jacques, Ed., Proc. SPIE 2975.

2. Grant, S. A. and R. S. Glass (1997), "Sol-Gel Based Fiber Optic pH Sensor," Laser-Tissue Interaction VIII, S. L. Jacques, Ed., Proc. SPIE 2975.

3. Grant, S. A. and R. S. Glass (1997), "A Sol-Gel Based Fiber Optic Sensor for Local Blood pH Measurements," Laser-Tissue Interaction VIII, S. L.

Jacques, Ed., Proc. SPIE 2975.

\section{Medical Photonics}

Refereed publications

1. Oraevsky, A. A., L. B. Da Silva, M. D. Feit, M. E. Glinsky, B. M. Mammini, K. L. Paquette, M. D. Perry, A. M. Rubenchik, W. Small IV, and B. C. Stuart (1996), "Ablation of Biological Tissues with Ultrashort Laser Pulses," SPIE, 2391A-33, Biomedical Optics '95, San Jose, CA.

2. DaSilva, L. B., B. C. Stuart, P. M. Celliers, T. D. Chang, M. D. Feit, M. E. Glinsky, N. J. Heredia, S. M. Herman, S. M. Lane, R. A. London, D. L. Matthews, J. Neev, M. D. Perry, and A. M. Rubenchik (1996), "Comparison of Soft and Hard Tissue Ablation with Sub-ps and ns Pulse Lasers," In Laser-Tissue Interaction VII, Steven L. Jacques, Ed., Proc. SPIE 2681, 196 (UCRL-JC-124044).

3. Glinsky, M. E., D. S. Bailey, and R. A. London (1997), "LATIS Modeling of Laser Induced Midplane and Backplane Spallation," Laser-Tissue Interaction VIII, S. L. Jacques, Ed., Proc. SPIE 2975, 374.

4. Strauss, M., P. A. Amendt, R. A. London, D. J. Maitland, M. E. Glinsky, C. P. Lin, and M. W. Kelly (1997), "Computational Modeling of Stress Transient and Bubble Evolution in Short-pulse Laser Irradiated Melanosome Particles," Laser-Tissue Interaction VIII, S. L. Jacques, Ed., Proc. SPIE 2975, 261.

5. Maitland, D. J., P. M. Celliers, P. A. Amendt, L. B. Da Silva, R. A. London, D. L. Matthews, M. Strauss, and S. R. Visuri (1997), "Simulations of Laser- 
Initiated Stress Waves," Laser-Tissue Interaction VIII, S. L. Jacques, Ed., Proc. SPIE 2975, 255.

6. Maitland, D. J., D. C. Eder, R. A. London, M. E. Glinsky, and B. A. Soltz (1997), "Dynamic Simulations of Tissue Welding," Lasers in Surgery: Adv. Characterization, Therapeutics and Systems VI, R. R. Anderson, Ed., Proc. SPIE 2671, 234.

7. Celliers, P. M., L. B. Da Silva, N. J. Heredia, B. M. Mammini, R. A. London, and M. Strauss (1997), "Dynamics of Laser-Induced Transients Produced by Nanosecond Duration Pulses," Lasers in Surgery: Adv. Characterization, Therapeutics and Systems VI, R. R. Anderson, Ed., Proc. SPIE 2671, 22.

8. Small IV, W., D. J. Maitland, N. J. Heredia, D. C. Eder, P. M. Celliers, L. B. Da Silva, R. A. London, and D. L. Matthews (1997), "Investigation of Laser Tissue Welding Dynamics via Experiment and Modeling," J. Clin. Laser Med. Surg., 15, 3.

Non-refereed publications

1. Visuri, S. R., P. M. Celliers, L. B. Da Silva, and D. L. Matthews (1997), "Effect of Viscosity on Bubble and Pressure Evolution," Laser-Tissue Interaction VIII, S. L. Jacques, Ed., Proc. SPIE 2975.

\section{Micro Technologies}

Meeting Abstracts

1. Krulevitch, P. A., A. P. Lee, P. B. Ramsey, and M. A. Northrup (1995), "Shape Memory Films for Microactuator Applications," Digest of Technical Papers, Micromachining Workshop II, Anaheim, CA, September 2 (UCRL-JC-121686).

2. Lee, A.P., S. L. Lehew, C. Yu, D. R. Ciarlo, and M. A. Northrup (1995), "Selective Eutectic Bonding of MEMS (1995)," Extended Abstracts of the 187th Meeting of The Electrochemical Society, Reno, NV 95-1, 413.

Refereed publications

1. Lee, A.P., K. Hong, J. Trevino, and M. A. Northrup (1996), "Thin Film Conductive Polymer for Microactuator and Micromuscle Applications," Proc. International Mechanical Engineering Congress \& Exposition, Symposium on Micro-Mechanical Systems (WAM '94), Chicago, IL, November 1994.

2. Lee, A.P., D. R. Ciarlo, P. A. Krulevitch, S. L. Lehew, J. C. Trevino, and M. A. Northrup (1995), "A Practical Microgripper by Fine Alignment, Eutectic Bonding, and SMA Actuation," Proc., 8th International Conference on Solid-State Sensors and Actuators 368 (UCRL-JC-120309).

3. Krulevitch, P., A. P. Lee, P. B. Ramsey, J. C. Trevino, J. Hamilton, and M. A. Northrup (1996), "Thin Film Shape Memory Alloy Microactuators," J. 
of Micro Electro Mechanical Systems, submitted Feb. 1996 (UCRL-JC123408).

4. Krulevitch, P., P. B. Ramsey, D. M. Makowiecki, A. P. Lee, M. A. Northrup, and G. C. Johnson (1996), "Mixed-Sputter Deposition of Ni-Ti-Cu Shape Memory Films," Physical, 1996274 101-105 (UCRL-JC-115719).

5. Lee, A.P., J. Hamilton, and J. Trevino (1996), "A Low Power, Tight Seal, Polymide Electrostatic Microvalve," MEMS Symposium of DSC, International Mechanical Engineering Congress \& Exposition, Atlanta, GA, November 17-22, 1996 (UCRL-JC-123423).

6. Lee, A.P., D.R. Ciarlo, P. A. Krulevitch, S. L. Lehew, J. C. Trevino, and M. A. Northrup (1995), "A Practical Microgripper by Fine Alignment, Eutectic Bonding, and SMA Actuation," Sensors and Actuators, (UCRL-JC-120309).

7. Krulevitch, P., P. B. Ramsey, D. M. Makowiecki, A. P. Lee, and M. A. Northrup (1996), "A Practical Microgripper by Fine Alignment, Eutectic Bonding and SMA Actuation," Physical, Sensors \& Actuators SNA054/1-3, 775-759 (UCRL-JC-120309).

8. Visuri, S. R., W. J. Benett, P. A. Krulevitch, R. A. London, and L. B. Da Silva, "Transducers for Optical to Mechanical Conversion," Laser-Tissue Interaction VIII, S. L. Jacques, Ed., Proc. SPIE 2975, 1997 Engineering Foundation Conference, Advanced in Optical Technologies for Medicine and Surgery.

9. Krulevitch, P. A., P. B. Ramsey, D. M. Makowiecki, A. P. Lee, and M. A. Northrup, "Mixed-Sputter Deposition of Ni-Ti-Cu Shape Memory Films," Thin Solid Films (UCRL-JC-115719).

10. Lee, A. P., S. Lehew, C. Yu, D. R. Ciarlo, and M. A. Northrup (1996), "Selective Eutectic Bonding of MEMS," Proceedings of the Wafer Bonding Symposium at the 187th Meeting of the Electrochemical Society, Reno, NV, May 24-28, 1995. 


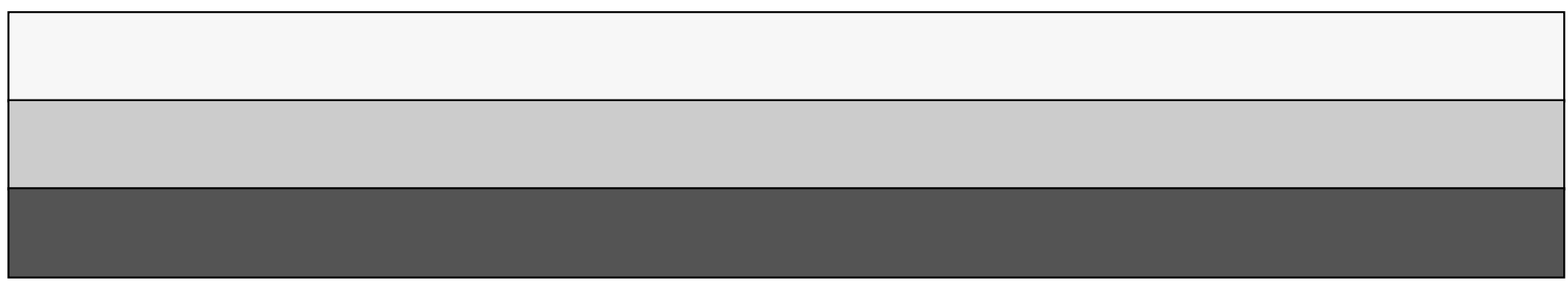

